\title{
Okul Aile İşbirliği Standartlarına İlişkin Veli Görüşlerinin İncelenmesi*
}

\section{Examining Parent Opinions about School-Parents Cooperation Standards}

\author{
Şakir ÇINKIR ${ }^{* *}$, Funda NAYIR ***
}

• Geliş Tarihi: 09.10.2015 • Kabul Tarihi: 03.02.2016• Yayın Tarihi: 31.01.2017

\begin{abstract}
ÖZ: Okul aile birlikleri okul yönetimleri üzerinde rol oynayan en önemli faktörlerden biridir. Okul aile birliklerinin kurulmasın temel amacı eğitim ve öğretim sürecinde onların desteğini almaktır. Okul aile birliklerinin amaçlarına ulaşabilmeleri için işlevlerinin ve standartlarının belirlenmesi önemlidir. Çalışmanın amacı ilköğretim okullarında çocuğu bulunan velilerin geliştirilen okul aile işbirliği standartlarına ilişkin görüşlerini ortaya çıkarmaktır. Araştırmanın çalışma grubunu Ankara merkez ilçelerde bulunan ilköğretim okullarında çocuğu okuyan 173 veli oluşturmaktadır. Araştırmada okul topluluğunca ailelerin hoş karşılanması, etkili iletişim, öğrenci başarısını desteklemek, çocukların hakkını gözetmek, güç paylaşımı, toplumla işbirliği olmak üzere altı boyuttan oluşan "Okul Aile İşbirliği Standartları" ölçeği kullanılmıştır. Araştırmada nitel ve nicel araştırma yöntemleri birlikte kullanılmıştır. Araştırma sonuçlarına göre veliler okul aile işbirliği standartlarına ilişkin ifadeleri önemli bulmakta ancak yeterince uygulanmadığını düşünmektedir. Velilerin görüşleri, cinsiyet, yaş, eğitim durumu, velinin sahip olduğu çocuk sayısı ve okula giden çocuk sayısı değişkenlerine göre anlamlı farklılık göstermektedir. Nitel verilerin analiz sonuçları incelendiğinde velilerin öncelikle okul aile birliği seçimlerinden haberi olmadığı ve okul aile birliklerinin eğitime katkısının olmadığını düşündükleri görülmektedir.
\end{abstract}

Anahtar Sözcükler: okul aile işbirliği standartları, veli, ilköğretim okulları.

\begin{abstract}
Parent-teacher associations are one of the most important factors that play a role on the school administrations. The main purpose of parent-teacher associations is to give necessary support in the process of teaching and learning. Therefore, in order to achieve its' objectives, determining the functions and standards for parent-teacher associations is vital. The purpose of the study is to reveal the views of elementary school parents concerning familyschool cooperation standards. In the study, the quantitative and qualitative research methods were used. The study group is composed of 173 parents whose children are the elementary school students in Ankara. As a data collection instrument, the scale of "School-Parents Cooperation Standards" which has six subscales including (1) welcoming all families into the school community, (2) communicating effectively, (3) supporting student success, (4) speaking up for every child, (5) sharing power, (6) collaborating with community was used. Among the key findings of the survey, parents think that standards concerning family school cooperation are important, however they have not been put into practice. There is a significant difference between the opinions of parents in terms of gender, age, and education status, number of children they have and number of children attending to school. From the analysis of qualitative data, it is concluded that,primarily, parents are not informed about the selection of parent-teachers association and they think that parent-teachers associations do not have any contribution to education.
\end{abstract}

Keywords: family-school cooperation, parents, elementary schools.

\section{GİRIŞ}

Son yıllarda okulun çocuğun eğitimi için tek başına yeterli olamadığının fark edilmesiyle birlikte okul-aile ve toplum işbirliğinin önemi arttığ söylenebilir. Ailelerin, çocuğun eğitim sürecine katılması, okulda çocuklarına nelerin öğretildiğini ve hangi konuların üzerinde durulduğunu takip etmesinin çocuğun okul başarısına katkı sağladığı söylemek mümkündür. Okulla yakından işbirliği kuran aileler, evde çocukları ile ilgili gözlemlerini öğretmenlerle paylaşırken aynı zamanda öğretmenlerin sınıfta uyguladıkları değişik tekniklerin öğretmen desteği ile kendileri tarafından evde de uygulanabileceğinin farkında olabileceklerdir. Kurulan işbirliği sayesinde anne ve babalar çocukların gelişimleri ve öğrenmeleri için elverişli bir eğitim ortamının

\footnotetext{
* Bu çalışma 24-26 Mayıs 2012 tarihleri arasında Malatya'da düzenlenen 7. Eğitim Yönetimi Kongresi’nde bildiri özeti olarak sunulmuştur.

** Doç. Dr., Ankara Üniversitesi, Eğitim Bilimleri Fakültesi, Ankara-Türkiye, cinkir@gmail.com

**** Yrd. Doç. Dr., Çankırı Karatekin Üniversitesi, Çankırı-Türkiye, fnayir@yahoo.com
} 
oluşmasına önemli derecede katkı sağlayabilir. Etkili bir okul-aile ve toplum işbirliğinin oluşturulmasında öğretmenlerin ailelerle açık bir iletişim ağı kurmaları önemlidir. Okul ve toplumla birlikte işbirliği yapan aileler, okulun ve öğrencilerin başarıları üzerinde rol oynayan faktörlerin başında yer almaktadır.

Okulda aile katılımının sağlanması ile ilgili politikaların belirlenmesi ve düzenlenmesi okul yönetimlerinin uğraştıkları konular arasında gelmektedir. Okulun girdilerinin başında gelen öğrenciler okulun bulunduğu çevreden gelmekte, dolayısıyla aile katılımı çocuğun eğitimini etkileyen faktörlerden biri olmaktadır. Sammons'da (1996) etkili bir okul aile işbirliği için ailenin okula katılımının en doğal hakkı olduğunu belirtmektedir. Aileler okula farklı şekillerde katılabilmektedir. Epstein'e (2001) göre aile katılımının ebeveynlik, iletişim, gönüllülük, evde öğretim etkinliklerine katılma, kararlara katılma ve toplumla işbirliği olmak üzere 6 çeşidi vardır. $\mathrm{Bu}$ katılımlar, okul ve toplumun bir arada olduğu ve birbirini etkileyen bir model sunar ve çocuğun gelişimi için oldukça önemlidir. Fan (2001) ise ailenin çocuktan beklediği akademik başarı, okul etkinliklerine katılma, öğrenmeyi destekleyen bir ev ortamı oluşturma ve çocukla okulla ilgili iletişim kurmanın aile katılımını oluşturduğunu belirtmiştir. Epstein (2001) ve Fan'ın (2001) belirttiği aile katılımı şekilleri incelendiğinde okul etkinliklerine katılma, iletişim ve evde öğrenme ortam oluşturma açısından benzerlik olduğu görülmektedir.

Çocuğun okulda geçirdiği zaman, ailesi ve çevresiyle geçirdiği zamana göre kısa olduğu için okul öğretmenlerinin aile tarafından desteklenmesi, çocuğun okul başarısı ve kişisel gelişimi için önem taşımaktadır. Çocuklarına evde destekleyici bir eğitim ortamı sağlayan aileler, sosyoekonomik durumları yetersiz olsa dahi çocuklarının okul başarısına olumlu yönde etkide bulunurlar (Tutkun ve Köksal, 2000, 220). Anne-baba ve öğretmenlerin, çocuklara uygun bir öğrenme ortam1 yaratabilmek için ortak bir çaba göstermesi ve okuldaki öğrenme girişimlerine destek sağlaması öğretmenin sınıf içi uygulamalarda daha başarılı olmasını sağlar (Burns, Roe ve Ross, 1992). Bunun için etkili bir okul aile işbirliğinin kurulması gerekir. Okul aile işbirliğinin etkililiğini arttırmak amacıyla Amerika'daki Ulusal Aile Öğretmen Derneği tarafından okul topluluğunca ailelerin hoş karşılanması, etkili iletişim, öğrenci başarısını desteklemek, çocuğun hakkını gözetmek, güç paylaşımı ve toplumla işbirliği olmak üzere altı standart belirlenmiştir (National Standards for Implementation Guide, 2009).

Okul topluluğunca ailelerin hoş karşılanması standardına göre aileler okula geldiğinde kendilerini değerli ve önemli hissederler. Öğrencilerin sınıfta ne yaptıklarıyla ilgili olarak birbirleriyle ve okul personeliyle iletişime geçerler. Bu standardın amacı konuksever bir okul iklimi yaratmak ve saygılı ve herkesi kapsayan bir okul toplumu oluşturmaktır. Etkili iletişim standardına göre okul personeli ve aileler arasında öğrencilerin öğrenmesiyle ilgili olarak düzenli ve çift yönlü bir iletişim kurulması gerekir. $\mathrm{Bu}$ standardın amacı bilgilerin okul ve aileler arasında paylaşılmasıdır. Öğrenci başarısını desteklemek standardına göre aileler ve okul personeli öğrencilerin başarısını desteklemek ve evde ve okulda sağlıklı bir eğitim oluşturmak için sürekli işbirliği içinde olmalı; bütün bunları daha etkili yapabilmek için bilgi ve becerilerini geliştirmelidir. $\mathrm{Bu}$ standardın amacı, öğrencilerin gelişimi ile ilgili bilgileri paylaşmak ve ailelerle ilgilenerek öğrenme sürecine destek olmaktır. Çocukların hakkını gözetmek standardına göre aileler hem kendi çocuklarının hem de diğer çocukların savunmakla, öğrencilere adil davranılmasını ve onların başarısını destekleyecek öğrenme firsatlarına ulaşmasını sağlamakla yetkilidir. Bu standardın amacı, okul sisteminin nasıl çalıştı̆̆ının anlaşılması ve aileleri kendi çocukları ve diğer çocukların başarısını desteklemek için yetkilendirmektir. Güç paylaşımı standardına göre aileler ve okul personeli çocukları ilgilendiren kararlarda eşit oy hakkına sahiptir. Okul programları ve politikaları hakkında aileler bilgilendirilir. $\mathrm{Bu}$ standardın amacı karar verme sürecinde ailelerin sesini duyurmak ve ailelerle politik ve sosyal ilişkiler oluşturmaktır. Toplumla işbirliği standardına göre, aileler ve okul personeli toplum üyeleriyle işbirliği yapar, toplum hizmetlerinin ve öğrenme fırsatlarının yayılması için uğraşır. $\mathrm{Bu}$ standardın amacı, toplum kaynaklarıyla okulu bütünleştirmektir (National Standarts for Implementation Guide, 2009). Bu standartlar Epstein'in 
(2001) belirttiği aile katılımı modeliyle ve Fan'ın (2001) belirttiği aile katılım şekilleriyle benzerlik göstermektedir.

Okul aile işbirliğinin okula, öğrenciye ve ailelere katkılarının saptanması amacıyla birçok çalışma yapılmıştır. Roberts (1984) çalışmasında düzenli olarak yapılan rehber öğretmen-veliöğrenci görüşmelerini değerlendirmiştir. Öğrenci ve veli tarafından yapılan değerlendirmeler öğrenci ve velilerin bu tür görüşmelerinin çok faydalı ve gerekli olduğunu göstermiştir. Diğer bir araştırma bulgusuna göre öğrencinin okuldaki gelişimi ailenin eğitime verdiği önem ile ilişkilidir (Berger, 1987). Berger'e göre aile-okul işbirliğinin iki avantajı vardır: Birincisi, ailenin okula ve öğrenciye gösterdiği ilgi, motivasyonu sağlar. İkincisi ise, okulun yapısını, değerlerini ve standartlarını tanıyan aileler çocuklarını daha iyi yönlendirebilirler. Griffith (1996) ve Chu ve Williams (1996) öğrenci başarısının okulların yapısı veya sosyo-ekonomik koşullarından ziyade aile-okul işbirliği ile arttı̆̆ını tespit etmişlerdir. Ancak, öğrenme ve davranış sorunları olan öğrencilerin ailelerinin öğretmenlerle yaptıkları görüşmelerin öğrencilerin okul-içi ve okul-dış1 faaliyetlerinden ziyade öğrencinin notları üzerinde yoğunlaştı̆̆ görülmüştür. Jacobs (1982) tarafindan yapılan araştırmada öğrencinin ihtiyaçlarını belirleme ve buna bağlı olarak sağlıklı bir yönlendirme programının uygulanabilmesi için ailenin okul ile işbirliğinin şart olduğu ortaya çıkmıştır. Bu araştırma sonucunda rehber öğretmenlerin de ailelerin öğrencilere karşı tutumlarının ne kadar önemli olduğunu göstermek açısından ailelere eğitim vermelerinin gerekli olduğu saptanmıştır. Birk ve Blimline (1984) ve Morgan, Dunn, Cairns ve Fraser (1993) ailenin çocuğun meslek seçiminde etkisini belirlemek üzere inceleme yapmışlardır. Yapılan incelemelerde, ailenin öğrencilerin meslek seçiminde önemli oldukları ve sağlıklı okul-aile işbirliğinin de öğrenciye sunulan seçeneklerin arttırılması ve gerekli bilgiler ile donatılması açısından çok önemli olduğunun tespit edildiği görülmüştür (akt. Demirbulak, 2000).

Araştırma bulguları aile katılımının öğrencilerinin öğrenme başarılarını artırdığını göstermekte (Griffifth, 1996; Marchant, Paulson ve Rothlisberg, 2001; Pomerantz ve Moorman, 2007; Jeynes, 2005) ve bu katılımın okul öncesi eğitimden liseden mezun olana kadar öğrencinin öğrenmesi üzerinde etkili olduğu (Hoover- Dempsey, Whitaker ve Ice, 2010,31) bilinmektedir. Çiftçi ve Bal'da (2015) araştırmalarında aile katılımıyla akademik başarı arasında pozitif bir ilişki olduğunu ortaya koymuştur. Aileler çocuklarının eğitim sürecine olumlu katılım sağladıkları zaman derslerinde yüksek başarı göstermekte, okula düzenli olarak devam etmekte, ödevlerini tamamlamakta, olumlu davranışlar sergilemekte, yüksek ortalama ile mezun olmakta ve yüksek öğretim programlarına devam etme şanslarının artmaktadır (Henderson ve Berla, 1994; Becher, 1984).

Türk eğitim sistemi açısından incelendiğinde okul aile işbirliğinin 1739 sayılı Milli Eğitim Temel Kanunu'nda yer alan 14 ilkeden biri olduğu görülmektedir. Buna göre "eğitim kurumlarının amaçlarının gerçekleştirilmesine katkıda bulunmak için okul aile arasında işbirliği sağlanır”. Başka bir deyişle okulun amaçlarını gerçekleştirmesi için okul aile işbirliğinin sağlanması gerekmektedir. Bu noktada okullarda okul aile birliklerinin kurulması konusu yasal düzenlemelerde de yer almıştır. Okul ile aile arasında işbirliğini sağlamak amacıyla ilk olarak 1940'lı yıllarda bir genelgeyle kurulan (Bayrakçı ve Dizbay, 2013) okul aile birliklerinin işleyişi okul aile işbirliği yönetmeliği ile düzenlenmiştir (2012). Buna göre okul aile birliğinin amacı, okul ile aile arasında bütünleşmeyi sağlamak, eğitim ve öğretimi geliştirici faaliyetleri desteklemek, maddi imkânlardan yoksun öğrencilere destek olmaktır (Madde 5). Görüldüğü gibi, okul ve aile işbirliğinin öncelikli amac1 çocukların eğitimine katkı sağlamaktır.

Okul aile işbirliğinin okul başarısını destekleyen faktörlerden biri olması okul aile işbirliğinin nasıl daha etkili olacağı sorusunun önemini artırmaktadır. Yıllardır okullarda okul aile birlikleri, okul koruma dernekleri gibi yapılanmalara gidilmesine rağmen; bunların işlevlerini beklenen düzeyde gerçekleştiremedikleri bir gerçektir. Araştırmalarda okul aile işbirliğinin önemi 
üzerinde durulmuş ( Çelenk, 2003; Çalışkan ve Ayık, 2015; Bayrakçı ve Dizbay, 2013) ancak bu işbirliğinin hangi boyutlarda olması gerektiğine ilişkin herhangi bir araştırmaya rastlanılmamıştır.

\subsection{Araştırmanın Amacı}

$\mathrm{Bu}$ araştırmanın amacı ilköğretim okulu velilerinin okul-aile işbirliği standartlarına ilişkin görüşlerini ortaya çıkarmaktadır. Bu amaç doğrultusunda aşağıdaki sorulara yanıt aranmıştır.

1. İlköğretim okulu velilerinin okul aile işbirliği standartlarına ilişkin görüşleri benimseme ve uygulama düzeyinde nasıldır?

2. İlköğretim okulu velilerinin okul aile işbirliği standartlarına ilişkin görüşleri benimseme ve uygulama düzeyinde cinsiyet, yaş, eğitim durumu, çocuk sayısı ve okula giden çocuk sayısı değişkenlerine göre anlamlı bir farklılık göstermekte midir?

3. İlköğretim okulu velilerinin okul aile birliği çalışmalarına ilişkin görüş ve önerileri nelerdir?

\section{YÖNTEM}

Amac1 ilköğretim okulu öğrenci velilerinin okul-aile işbirliği standartlarına ilişkin görüşlerini belirlemek olan araştırma tarama türünde olup nitel ve nicel veriler eş zamanlı toplanarak zenginleştirilmiş desen (triangulation design) (Büyüköztürk, Çakmak, Akgün, Karadeniz ve Demirel, 2010, 266) kullanılmıştır. Bu desenin kullanılma nedeni araştırmanın amaçlarına ilişkin olarak veli görüşlerinin nicel verilerle daha etkili ortaya koyulması, nitel verilerin ise velilerin okul aile birliği çalışmalarına ilişkin görüşlerinin daha ayrıntılı ortaya çıkarmasıdır.

\section{1. Çalışma Grubu}

Araştırmanın çalışma grubunu 2012 - 2013 eğitim-öğretim yılında Ankara Büyükşehir belediye sinırları içerisinde bulunan dokuz ilçenin her birinden rastgele örnekleme yöntemiyle seçilen üç ilköğretim okulu olmak üzere toplam 27 okul ile her okulda çocuğu okuyan 10 veli olmak üzere toplam 270 veli oluşturmaktadır (Tablo 1).

Araştırma için 27 okula toplam 300 ölçek dağıtılmış geri dönen ölçeklerden 173 tanesi araştırmada kullanılmıştır. Katılımcılara ilişkin demografik özellikler Tablo 1 de verilmiştir. Tablo 1 incelendiğinde katılımcıların çoğunluğunun kadın, ilkokul ve lise mezunu ve 24-43 yaş aralığında olduğu görülmektedir. 
Tablo 1: Katılımcılara ilişkin demografik özellikler

\begin{tabular}{|c|c|c|c|}
\hline Değişkenler & & $\mathbf{n}$ & $\%$ \\
\hline \multirow[t]{2}{*}{ Cinsiyet } & Kadın & 119 & 68.8 \\
\hline & Erkek & 54 & 31.2 \\
\hline \multirow[t]{4}{*}{ Yaş } & 25-33 Aras1 & 48 & 27.7 \\
\hline & $34-43$ aras1 & 89 & 51.4 \\
\hline & 44 ve üzeri & 31 & 17.9 \\
\hline & Kayıp değer & 5 & 2.9 \\
\hline \multirow[t]{4}{*}{ Eğitim Durumu } & İlkokul & 60 & 34.7 \\
\hline & Lise & 62 & 35.8 \\
\hline & Üniversite & 41 & 23.7 \\
\hline & Kayıp değer & 10 & 5.8 \\
\hline \multirow[t]{2}{*}{ Çocuk Sayısı } & $1-2$ & 111 & 64.2 \\
\hline & 3 ve üzeri & 62 & 35.8 \\
\hline \multirow[t]{3}{*}{ Okula Giden Çocuk Sayısı } & 1 & 62 & 35.8 \\
\hline & 2 & 76 & 43.9 \\
\hline & 3 & 35 & 20.2 \\
\hline
\end{tabular}

\subsection{Veri Toplama Aracının Geliştirilmesi ve Uygulanması}

Veri toplama aracı olarak araştırmacılar tarafından geliştirilen "Okul Aile İşbirliği Standartları Ölçeği” kullanılmıştır. Ölçek geliştirme sürecinde öncelikle ilgili alan yazın taranmış, ayrıca Virginia Ulusal PTA Merkezi tarafından geliştirilen standartlardan yararlanılmıştır. Ölçek hazırlanırken Virginia Ulusal PTA Merkezi'nin belirlediği altı standart ve standartlara ilişsin açıklamalar dikkate alınarak ölçek maddeleri yazılmıştır. Hazırlanan ölçek yedi uzman görüşüne sunulmuş maddelerin kapsam geçerliği ile ilgili olarak görüşleri alınmıştır. Tüm uzmanların $\% 70$ ve üzeri oranında uygulanabilir bulduğu maddeler alınarak ölçeğe son şekli verilmiştir. İki bölümden oluşan ölçek, beşli likert tipi derecelemeye göre hazırlanmıştır. Birinci bölümde kişisel bilgilere yer verilmiştir. Ölçeğin ikinci bölümü "Okul Topluluğunca Ailelerin Hoş Karşılanması”, "Etkili İletişim", "Öğrenci Başarısını Desteklemek", "Çocuğun Hakkını Gözetmek", "Güç Paylaşımı" ve "Toplumla İşbirliği" olmak üzere altı alt boyuttan oluşmaktadır. Ölçeğin son bölümünde velilerin okul aile işbirliği çalışmalarına ilişkin görüş ve önerileri alınmıştır.

Ölçeğin alanyazında belirlenen altı faktörlü yapısının örneklem grubundan elde edilen verilerle uyumu doğrulayıcı faktör analizi (DFA) ile test edilmiştir (Bentler ve Bonett, 1980; Brown, 2015). DFA, faktör sayılarının ve gözlenen değişkenlerin belirlendiği bir ölçme modelidir (Kline, 2011). Bu nedenle, gözlenen değişkenler kuramın sayıltıları doğrultusunda seçilir ve bu değişkenlerin faktörlerde hangi oranda bulunduklarına bakılır (Sümer, 2000). DFA'da, göstergeler arası ilişkilerin düzenlenebilmesi için daha iyi faktör çözümlemesinin nasıl yapılabileceğiyle ilgili istatistiksel değerlendirmeye olanak sağlayan en çok olabilirlik yöntemi kullanılmıştır (Brown, 2015). Bununla birlikte her bir faktör için Cronbah alfa katsayısı hesaplanmıştır. DFA LISREL 8.80 programı aracıllğıyla yürütülmüştür.

DFA, sırasıyla ölçeğin uygulama ve önem düzeyleri için ayrı ayrı yapılmıştır. Uygulama düzeyiyle ilgili DFA'dan elde edilen bulgularda ilk olarak her maddeye ait t değeri incelenmiştir. 
Kline (2011) ve Şimşek (2007) sınırdaki t değerinin .05 düzeyinde 1.96 olduğunu belirtmektedirler. Ölçek maddelerinin $\mathrm{t}$ değerlerinin $\mathrm{t}=4.11>1.96$ (madde 12) ile $\mathrm{t}=12.90>1.96$ (madde 38) arasında değiştiği görülmüştür $\mathrm{p}<.05$. DFA'da ikinci olarak Tablo 2'de sınır değerleri sunulan uyum indeksleri incelenmiştir (Hooper, Coughlan ve Mullen, 2008; Hoyle ve Smith, 1994; Hu ve Bentler, 1998; MacCallum, Widaman, Preacher ve Hong, 2001; Schermelleh-Engel, Moosbrugger ve Müller, 2003; Sümer, 2000; Şimşek, 2007).

Tablo 2: Uyum ölçüleri ve ölçeğin uygulama düzeyine ilişkin uyum indeksleri

\begin{tabular}{lcrc}
\hline \multicolumn{1}{c}{ Uyum Ölçüleri } & \multicolumn{1}{c}{ İyi } & Kabul Edilebilir & Ölçme Modeli \\
\hline$\chi^{2}$ & $0 \leq \chi^{2} \leq 2 \mathrm{sd}$ & $2 \mathrm{sd}<\chi^{2} \leq 3 \mathrm{sd}$ & 1940.97 \\
$\chi^{2} /$ sd & $<2$ & $\leq 3,<5$ & 1.90 \\
RMSEA & $\leq .05,<.07$ & $\leq .08, \leq .10$ & .07 \\
NFI & $>.95$ & $\geq .90$ & .93 \\
NNFI & $>.95, \geq .97$ & $>.90, \geq .95$ & .96 \\
CFI & $\geq .97$ & $>.90, \geq .95$ & .96 \\
SRMR & $\leq .05,<.08$ & $\leq .10$ & .07 \\
IFI & $\geq .95$ & $\geq .90$ & .96 \\
RFI & $\geq .90$ & $\geq .85$ & .92 \\
\hline
\end{tabular}

Tablo 2'de görüldüğü üzere DFA sonucunda uyum indekslerinden $\chi 2=1940.97$, sd=1019, değerleri kabul edilebilir düzeyde; $\chi 2 / \mathrm{sd}=1.90, \mathrm{RMSEA}=.07, \mathrm{NFI}=.93, \mathrm{NNFI}=.96, \mathrm{CFI}=.96$, $\mathrm{SRMR}=.07, \mathrm{IFI}=.96, \mathrm{RFI}=.92$ değerleri ise iyi düzeyde uyuma işaret etmiştir. Bulgular, örneklem grubunun büyüklüğüne bağlı olarak model veri uyumunun yeterli düzeyde olduğunu göstermiştir. DFA'da üçüncü olarak maddelerin faktör yük değerleri (Şekil 1) ve açıklanan varyans oranları incelenmiştir.

Şekil 1'den inceleneceği üzere, sırasıyla, "Okul Topluluğunca Ailelerin Hoş Karşılanması" alt boyutunu oluşturan maddeler .48 ile .67; "Etkili İletişim" alt boyutunu oluşturan maddeler .47 ile .67; "Öğrenci Başarısını Desteklemek" alt boyutunu oluşturan maddeler .51 ile .82; "Çocuğun Hakkını Gözetmek" alt boyutunu oluşturan maddeler .65 ile .84; "Güç Paylaşımı" alt boyutunu oluşturan maddeler .67 ile .87; "Toplumla İşbirliği" alt boyutunu oluşturan maddeler .54 ile .79 arasında değişen faktör yük değerleri almışlardır. Açıklanan varyans oranları incelendiğinde "Okul Topluluğunca Ailelerin Hoş Karşılanması" alt boyutuna ilişkin değişkenliğin en çok üçüncü madde .45 , en az ise birinci madde .23 , tarafından açıklandığı belirlenmiştir. "Etkili İletişim" alt boyutuna ait varyans oranları, değişkenliğin en çok on birinci madde .45 , en az ise on ikinci madde .18 , tarafından açıklandığını göstermiştir. "Öğrenci Başarısını Desteklemek" alt boyutuna ilişkin değişkenliğin en çok yirminci .68 , en az yirmi üçüncü madde .26, tarafından açıklandığı tespit edilmiştir. "Çocuğun Hakkını Gözetmek" alt boyutuna ait varyans oranları, değişkenliğin en çok otuz dördüncü madde .70 , en az otuz altıncı madde .42 , tarafindan açıklandığına işaret etmiştir. "Güç Paylaşımı" alt boyutuna ilişkin değişkenliğin en çok otuz sekizinci madde .77, en az kırkıncı madde .40, tarafından açıklandığı bulunmuştur. "Toplumla İşbirliği" alt boyutuna ait varyans oranları ise değişkenliğin en çok kırk üçüncü madde .62, en az kırk yedinci madde .29 , tarafından açıklandığını göstermiştir. Elde edilen bulgular bütünsel anlamda değerlendirildiğinde, ölçeğin uygulama düzeyinin, altı alt boyut altında 47 maddeden oluştuğu saptanmış ve model doğrulanmıştır. Önem düzeyiyle ilgili DFA sonucunda öncelikle her maddeye ait $t$ değeri incelenmiştir. Ölçek maddelerinin $t$ değerlerinin $t=4.32>1.96$ (madde 9) ile $t=10.02>1.96$ (madde 30) arasında değiştiği görülmüsstür $\mathrm{p}<.05$. DFA'da Tablo 3 'te sınır değerleri sunulan uyum indeksleri de incelenmiştir. 


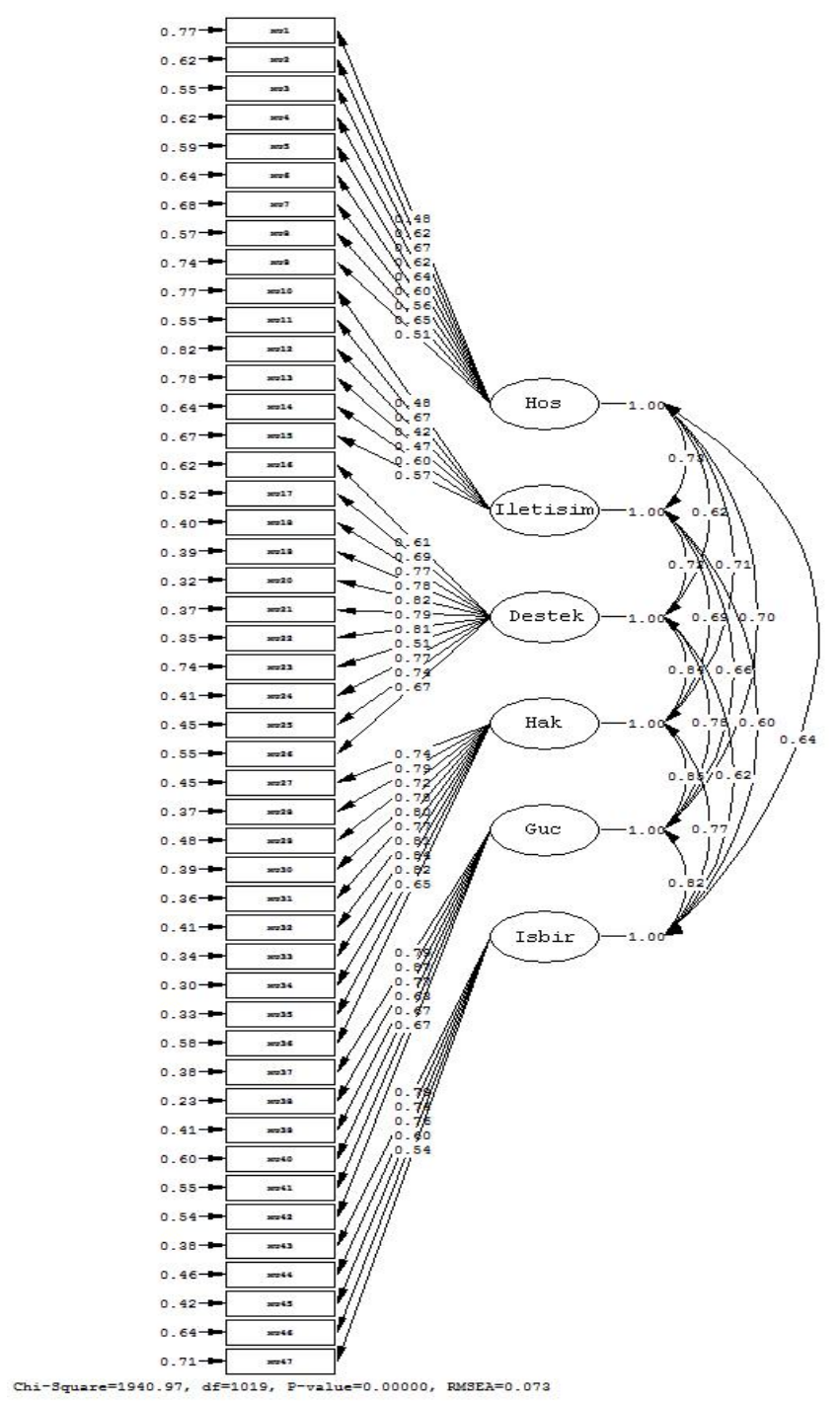

Şekil 1. Okul aile işbirliği standartları ölçeği uyum düzeyi doğrulayıcı faktör analizi

Tablo 3: Uyum ölçüleri ve ölçeğin önem düzeyine ilişkin uyum indeksleri

\begin{tabular}{lccc}
\hline \multicolumn{1}{c}{ Uyum Ölçüleri } & İyi & Kabul Edilebilir & Ölçme Modeli \\
\hline$\chi^{2}$ & $0 \leq \chi^{2} \leq 2 \mathrm{sd}$ & $2 \mathrm{sd}<\chi^{2} \leq 3 \mathrm{sd}$ & 2366.21 \\
$\chi \mathbf{2} /$ sd & $<2$ & $\leq 3,<5$ & 2.32 \\
RMSEA & $\leq .05,<.07$ & $\leq .08, \leq .10$ & .08 \\
NFI & $>.95$ & $\geq .90$ & .90 \\
NNFI & $>.95, \geq .97$ & $>.90, \geq .95$ & .94 \\
CFI & $\geq .97$ & $>.90, \geq .95$ & .94 \\
SRMR & $\leq .05,<.08$ & $\leq .10$ & .07 \\
IFI & $\geq .95$ & $\geq .90$ & .94 \\
RFI & $>.90$ & $>.85$ & .89 \\
\hline
\end{tabular}


Tablo 3'de görüldüğü üzere DFA sonucunda uyum indekslerinden $\chi 2=2366.21$, sd $=1019$, $\chi 2 / \mathrm{sd}=2.32, \mathrm{RMSEA}=.08, \mathrm{NFI}=.90, \mathrm{NNFI}=.94, \mathrm{CFI}=.94, \mathrm{IFI}=.94, \mathrm{RFI}=.89$ değerleri kabul edilebilir düzeyde; $\mathrm{SRMR}=.07$ değer ise iyi düzeyde uyuma işaret etmiştir. Bulgular, örneklem grubunun büyüklügüne bağlı olarak model veri uyumunun kabul edilebilir düzeyde olduğunu göstermiştir. DFA'da son olarak maddelerin faktör yük değerleri (Şekil 2) ve açıklanan varyans oranları incelenmiștir.

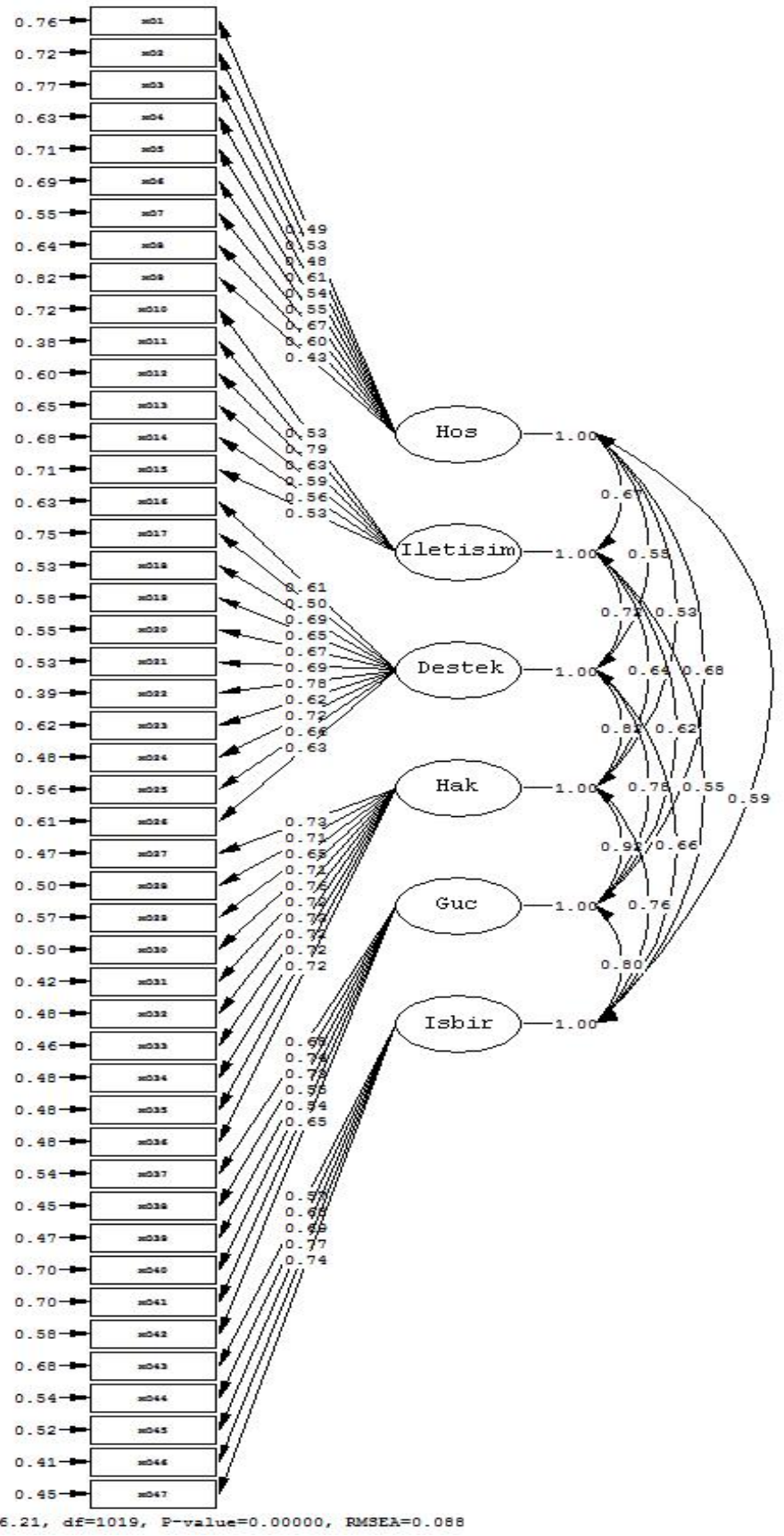

\section{Şekil 2. Okul aile işbirliği standartları ölçeği önem düzeyi doğrulayıcı faktör analizi}

Şekil 2'den inceleneceği üzere, sırasıyla, "Okul Topluluğunca Ailelerin Hoş Karşılanması" alt boyutunu oluşturan maddeler .43 ile .67; "Etkili İletişim" alt boyutunu oluşturan maddeler .53 ile .79; "Öğrenci Başarısını Desteklemek" alt boyutunu oluşturan maddeler .50 ile .78; "Çocuğun Hakkını Gözetmek" alt boyutunu oluşturan maddeler .65 ile .73; "Güç Paylaşımı" alt boyutunu 
oluşturan maddeler .55 ile .74; "Toplumla İşbirliği" alt boyutunu oluşturan maddeler .57 ile .77 arasında değişen faktör yük değerleri almışlardır. Açıklanan varyans oranları incelendiğinde "Okul Topluluğunca Ailelerin Hoş Karşılanması" alt boyutuna ilişkin değişkenliğin en çok yedinci madde .45 , en az ise dokuzuncu madde .18, tarafından açıklandığı belirlenmiştir. "Etkili İletişim" alt boyutuna ait varyans oranları, değişkenliğin en çok on birinci madde .62, en az ise onuncu madde .28, tarafından açıklandığını göstermiştir. "Öğrenci Başarısını Desteklemek" alt boyutuna ilişkin değişkenliğin en çok yirmi ikinci .61 , en az on yedinci madde .25 , tarafından açıklandığı tespit edilmiştir. "Çocuğun Hakkını Gözetmek" alt boyutuna ait varyans oranları, değişkenliğin en çok otuz birinci madde .58 , en az yirmi dokuzuncu madde .43 , tarafından açıklandığına işaret etmiştir. "Güç Paylaşımı" alt boyutuna ilişkin değişkenliğin en çok otuz sekizinci madde .55, en az kırkıncı madde .30 , tarafından açıklandığı bulunmuştur. "Toplumla İşbirliği" alt boyutuna ait varyans oranları ise değişkenliğin en çok kırk altıncı madde .59, en az kırk üçüncü madde .32, tarafından açıklandığını göstermiştir. Elde edilen bulgular bütünsel anlamda değerlendirildiğinde, ölçeğin önem düzeyinin, uygulama düzeyine benzer olarak, altı alt boyut altında 47 maddeden oluştuğu saptanmış ve model doğrulanmıştır. Sonuç olarak, ölçeğin uygulama ve önem düzeyine ait birinci alt boyutu 9 maddeden, ikinci alt boyutu 6 maddeden, üçüncü alt boyutu 11 maddeden, dördüncü alt boyutu 10 maddeden, beşinci alt boyutu 6 maddeden ve altınc1 alt boyutu 5 maddeden oluşmuştur. Bulgulara dayalı olarak, "Okul Aile İşbirliği Standartları Ölçeği”nin yapısal ve istatiksel olarak uygun bir ölçek olduğu söylenebilir.

Ölçeğin iç tutarlığını belirleyen Cronbach alfa katsayısı, uygulama düzeyinde, birinci alt boyut için .83 , ikinci alt boyut için .70 , üçüncü alt boyut için .92 , dördüncü alt boyut için .94 , beşinci alt boyut için .87 ve altıncı alt boyut için .81 olarak hesaplanmıştır. Cronbach alfa katsayısı, önem düzeyinde, birinci alt boyut için .79 , ikinci alt boyut için .75 , üçüncü alt boyut için .88 , dördüncü alt boyut için .90 , beşinci alt boyut için .78 ve altıncı alt boyut için .80 olarak bulunmuştur. Bulgulardan hareketle, ölçek için yeterli düzeyde iç tutarlık değerlerine ulaşıldığ söylenebilir. Ayrıca her alt boyutun altında öğretmenlerin bu alt boyutla ilgili farklı görüşlerini de almak üzere açık uçlu bir soruya yer verilmiştir. Ölçeğin sonunda, velilerin, okul aile birliği standartları ile ilgili önerilerini belirtmelerinin istendiği açık uçlu sorulara yer verilmiştir.

\subsection{Verilerin Analizi}

Toplanan veriler, SPSS 13.0 programı ile analiz edilmiştir. Nicel verilerin çözümlenmesinde öncelikle veri dosyasında uç değer taraması yapılmış ve dağılımın normalliği test edilmiş ve değişkenlere göre dağılımın normal olduğu görülerek parametrik testlerin kullanılmasına karar verilmiştir. Velilerin, okul aile işbirliği standartlarına ilişkin görüşlerinin cinsiyet ve çocuk sayısı değişkenlerine göre farklılaşıp farklılaşmadığı t-testi, yaş, eğitim durumu, okula devam eden çocuk sayısı değişkenlerine göre farklılaşıp farklılaşmadığı tek yönlü varyans (ANOVA) analizi ile test edilmiştir. Nicel verilerin çözümlenmesinde manidarlık için anlamlılık düzeyi $\alpha=0.05$ alınmıştır. Tek yönlü varyans analizi (ANOVA) sonucunda ortaya çıkan farkların kaynağının belirlenmesi için Scheffe testi kullanılmıştır.

Nitel verilerin inandırıcılığı için öncelikle velilerin açık uçlu sorulara verdiği yanıtlar soru maddelerine göre ayrılarak tek tek dökümü yapılmış ve her biri soru için benzer görüşler bir araya toplanmıştır. Oluşturulan temalarda benzer görüşlerin bir arada olmasına ve ilgisiz görüsslerin dışarıda kalmasına dikkat edilmiş, temalar arasındaki ilişki göz önünde bulundurulmuştur. Analizler yapılırken kodlamalar araştırmacılar tarafından ayrı ayrı yapılmıştır. Buna göre uyuşum yüzdesi \%84 olarak hesaplanmıştır. Verilerin aktarılabilirliği için temaları içeren görüşler doğrudan alıntı yapılarak verilmiştir. 


\section{BULGULAR}

Çalışmanın alt amaçlarına ilişkin olarak ilköğretim okulu velilerinin okul aile işbirliği standartlarına ilişkin görüşleri benimseme ve uygulama düzeyinde incelenmiştir. Buna göre, okul topluluğunca aileleri hoş karşılama boyutunun önem düzeyine ilişkin veli görüşlerinin aritmetik ortalaması 4.77 ile 4.13 arasında değişmektedir. Veliler bu boyuttaki ifadelere çok ya da tamamen katılmaktadırlar. Velilerin bu boyutta en çok katıldığı ilk iki madde "Okulda tüm ailelere eşit davranılır" ( $\overline{\mathrm{X}}=4.77)$ ve "Okulda herkes için aile dostu bir ortam vardır" $(\overline{\mathrm{X}}=4.31)$ maddeleridir. Velilerin en az katıldığı son iki madde "Okula gelen ailelere okula ait oldukları hissettirilir" ( $\bar{X}$ $=4.13)$ ve "Tüm ailelerin okul etkinliklerine gönüllü katılımını sağlamak için çaba harcanır" ( $\bar{X}$ $=4.14$ ) maddeleridir.

Okul topluluğunca aileleri hoş karşılama davranışlara uygulama düzeyine ilişkin veli görüşlerinin aritmetik ortalaması 3.98 ile 3.23 arasında değişmektedir. Veliler bu boyuttaki ifadelere orta derecede katılmaktadırlar. Velilerin bu boyutta en çok katıldığı ilk iki madde "Okuldaki tüm etkinlikler ailelere açıktır" $\left(\overline{\mathrm{X}}_{=3.98}\right)$ ve "Okulda tüm ailelere eşit davranılır" $(\overline{\mathrm{X}}$ =3.91) maddeleridir. Velilerin en az katıldığı son iki madde "Okula gelen ailelere okula ait oldukları hissettirilir" ( $\overline{\mathrm{X}}=3.23$ ) ve "Okul personeli ailelerin okul etkinliklerine katılımının önündeki engelleri ortadan kaldırmak için çalışır” ( $\overline{\mathrm{X}}=3.39)$ maddeleridir.

Etkili iletişim sağlama boyutunun önem düzeyine ilişkin veli görüşlerinin aritmetik ortalaması 4.79 ile 4.11 arasında değişmektedir. Veliler bu boyuttaki ifadelere çok ya da tamamen katılmaktadırlar. Velilerin bu boyutta en çok katıldığı ilk iki madde "Öğretmenler ailelerle düzenli iletişim kurar" ( $\bar{X}=4.79)$ ve "Okul önemli konular veya olaylardan aileleri haberdar eder" ( $\bar{X}$ $=4.67$ ) maddeleridir. Bu boyutta velilerin en az katıldığı son iki madde "Okul aile birliği aileleri kaynaştırmak için uğraşır" ( $\overline{\mathrm{X}}=4.11)$ ve "Okul aile birliği ailelerin görüşlerini almak için araştırmalar yapar" $(\overline{\mathrm{X}}=4.28)$ maddeleridir.

Etkili iletişim sağlama boyutunun uygulama düzeyine ilişkin veli görüşlerinin aritmetik ortalaması 4.29 ile 2.67 arasında değişmektedir. Veliler bu boyuttaki ifadelere çok veya orta derecede katılmaktadırlar. Velilerin bu boyutta en çok katıldığı maddeler "Aileler her zaman okul yönetimine ulaşabilir" ( $\bar{X}=4.29)$ ve "Öğretmenler ailelerle düzenli iletişim kurar" $(\bar{X}=4.16)$ maddeleridir. $\mathrm{Bu}$ boyutta velilerin en az katıldığı son iki madde "Okul aile birliği ailelerin görüşlerini almak için araştırmalar yapar" ( $\overline{\mathrm{X}}=2.67)$ ve "Okul aile birliği aileleri kaynaştırmak için uğraşır" ( $\overline{\mathrm{X}}=2.75)$ maddeleridir.

Öğrenci başarısını desteklemek boyutunun önem düzeyine ilişkin veli görüşlerinin aritmetik ortalaması 4.77 ile 4.31 arasında değişmektedir. Veliler bu boyuttaki ifadelere çok ya da tamamen katılmaktadırlar. Velilerin bu boyutta en çok katıldığı ilk iki madde "Tüm öğrenciler yapabileceklerinin en iyisini yapmak için cesaretlendirilir" ( $\left.\bar{X}_{=4.77}\right)$ ve "Aileler çocuklarının okul başarısı hakkında bilgilendirilir" ( $\left.\bar{X}_{=4.74}\right)$ maddeleridir. Bu boyutta velilerin en az katıldığı son iki madde "Aileler çocuklarının sınıfını gözlemlemesi için davet edilir" $(\overline{\mathrm{X}}=4.31)$ ve "Çocukların evde öğrenmelerinin geliştirilmesi için ailelere yardım ediliı" ( $\left.\bar{X}_{=4.49}\right)$ maddeleridir. 
Öğrenci başarısını desteklemek boyutunun uygulama düzeyine ilişkin veli görüşlerinin aritmetik ortalaması 4.18 ile 2.77 arasında değişmektedir. Veliler bu boyuttaki ifadelere orta derecede katılmaktadırlar. Velilerin bu boyutta en çok katıldığı ilk iki madde "Aileler çocuklarının okul başarısı hakkında bilgilendirilir" $(\overline{\mathrm{X}}=4.18)$ ve "Aileler ve öğretmenler çocukların gelişimi konusunda iletişim kurarlar" ( $\overline{\mathrm{X}}=3.97)$ maddeleridir. Bu boyutta velilerin an az katıldığ son iki madde "Aileler çocuklarının sınıfını gözlemlemesi için davet edilir" ( $\bar{X}=2.77)$ ve "Okul dışında çocuklar için ne tür öğrenme firsatlarının olduğu konusunda ailelere destek verilir" ( $\overline{\mathrm{X}}=3.06)$ maddeleridir.

Çocukların hakkını gözetmek boyutunun önem düzeyine ilişkin veli görüşlerinin aritmetik ortalaması 4.59 ile 4.08 arasında değişmektedir. Veliler bu boyuttaki ifadelere çok ya da tamamen katılmaktadırlar. Velilerin bu boyutta en çok katıldığı ilk iki madde "Ailelere sorunların nasıl çözüleceği hakkında bilgi verilir" $\left(\bar{X}_{=4.59}\right)$ ve "Ailelere çocuklarının gelişiminin izlenmesi konusunda bilgi verilir" ( $\overline{\mathrm{X}}=4.57)$ maddeleridir. Bu boyutta velilerin en az katıldığı son iki madde "Ailelere okul personelinin görevleri hakkında bilgi verilir" $(\overline{\mathrm{X}}=4.08)$ ve "Ailelere öğrenci kıyafeti ve davranışları içi gerekli olan kurallar hakkında bilgi verilir $\left(\overline{\mathrm{X}}_{=4.42}\right)$ maddeleridir.

Çocukların hakkını gözetmek boyutunun uygulama düzeyine ilişkin veli görüşlerinin aritmetik ortalaması 4.01 ile 2.70 arasında değişmektedir. Veliler bu boyuttaki ifadelere çok ya da orta derecede katılmaktadırlar. Velilerin bu boyutta en çok katıldığı ilk iki madde "Ailelere öğrenci kıyafeti ve davranışları için gerekli olan kurallar hakkında bilgi verilir" ( $\overline{\mathrm{X}}=4.01)$ ve "Ailelere sorunların nasıl çözüleceği hakkında bilgi verilir" ( $\bar{X}=3.43)$ maddeleridir. Bu boyutta velilerin en az katıldığı son iki madde "Ailelere okul personelinin görevleri hakkında bilgi verilir" $(\bar{X}=2.70)$ ve “Ailelere hakları ve sorumlulukları hakkında bilgi verilir” $(\overline{\mathrm{X}}=3.12)$ maddeleridir.

Güç paylaşımı boyutunun önem düzeyine ilişkin veli görüşlerinin aritmetik ortalaması 4.59 ile 3.98 arasında değişmektedir. Veliler bu boyuttaki ifadelere çok ya da tamamen katılmaktadırlar. Velilerin bu boyutta en çok katıldığı ilk iki madde "Çocuklarla ilgili alınacak kararlarda ailelerin görüşüne başvurulur" ( $\left.\overline{\mathrm{X}}_{=4.59}\right)$ ve "Okulda çocuklarla ilgili alınacak kararlarda ailelerin oy hakk1 vardır" ( $\left.\overline{\mathrm{X}}_{=4.58}\right)$ maddeleridir. Velilerin bu boyutta en az katıldığ 1 son iki madde "Okul ailelerin yerel yöneticilerle (kaymakam, belediye vb) bağlantı kurmalarına yardımcı olur" ( $\bar{X}=3.98)$ ve "Okulda okul personeli, veli ve toplum liderlerini bir araya getirecek etkinlikler düzenlenir" ( $\overline{\mathrm{X}}$ $=4.19$ ) maddeleridir.

Güç paylaşımı boyutunun uygulama düzeyine ilişkin veli görüşlerinin aritmetik ortalaması 3.58 ile 2.52 arasında değişmektedir. Veliler bu boyuttaki ifadelere orta derecede ya da az katılmaktadırlar. Velilerin bu boyutta en çok katıldığı ilk iki madde "Çocuklarla ilgili alınacak kararlarda ailelerin görüşüne başvurulur" $(\overline{\mathrm{X}}=3.58)$ ve "Okul aile birliği tüm aileleri eşit olarak temsil eder" ( $\overline{\mathrm{X}}=3.46)$ maddeleridir. Velilerin bu boyutta en az katıldı̆̆ son iki madde "Okul ailelerin yerel yöneticilerle (kaymakam, belediye vb) bağlantı kurmalarına yardımcı olur" ( $\bar{X}$ $=2.52$ ) ve "Okulda okul personeli, veli ve toplum liderlerini bir araya getirecek etkinlikler düzenlenir" ( $\overline{\mathrm{X}}=3.00)$ maddeleridir. 
Toplumla işbirliği boyutunun önem düzeyine ilişkin veli görüşlerinin aritmetik ortalaması 4.55 ile 4.20 arasında değişmektedir. Veliler bu boyuttaki ifadelere çok ya da tamamen katılmaktadırlar. Velilerin bu boyutta en çok katıldığı ilk iki madde "Toplum üyeleri tarafından verilen destekler okulun ihtiyaçları doğrultusunda kullanılır" $\left(\bar{X}_{=4.55}\right)$ ve "Aileler ve okul yöneticileri okulu geliştirmek için tüm paydaşlarla birlikte çalışır" $(\overline{\mathrm{X}}=4.41)$ maddeleridir. $\mathrm{Bu}$ boyutta velilerin en az katıldığı son iki madde "Toplumsal kaynaklara ulaşmak için aileler sürece katılır" ( $\left.\overline{\mathrm{X}}_{=4.20}\right)$ ve "Okul toplumsal kaynaklara (hastane, iş çevreleri, dernekler...) ulaşmak için gerekli bağlantılar kurar" $(\overline{\mathrm{X}}=4.26)$ maddeleridir.

Topumla işbirliği boyutunun uygulama düzeyine ilişkin veli görüşlerinin aritmetik ortalaması 3.92 ile 2.98 arasında değişmektedir. Veliler bu boyuttaki ifadelere orta derecede ya da az katılmaktadırlar. Velilerin bu boyutta en çok katıldığı ilk iki madde "Toplum üyeleri tarafından verilen destekler okulun ihtiyaçları doğrultusunda kullanılır" $(\overline{\mathrm{X}}=3.92)$ ve "Aileler ve okul yöneticileri okulu geliştirmek için tüm paydaşlarla birlikte çalışır” ( $\overline{\mathrm{X}}=3.38)$ maddeleridir. $\mathrm{Bu}$ boyutta velilerin en az katıldığı son iki madde "Toplumsal kaynaklara ulaşmak için aileler sürece katılır" ( $\overline{\mathrm{X}}=2.98)$ ve "Okul toplumsal kaynaklara (hastane, iş çevreleri, dernekler...) ulaşmak için gerekli bağlantılar kurar" $(\overline{\mathrm{X}}=3.14)$ maddeleridir.

Velilerin önem düzeyine ilişkin görüşleri incelendiğinde, görüşlerinin okul topluluğunca aileleri hoş karşılama boyutunda çocuk sayısı, yaş ve okula giden çocuk sayısı değişkenlerine, öğrenci başarısını desteklemek boyutunda yaş değişkenine göre farklılaştı̆̆ ortaya çıkmıştır. Bu değişkenlere göre yapılan t-testi sonuçları Tablo 4'de ve ANOVA sonuçları Tablo 5'te verilmiştir.

Tablo 4: Çocuk sayısı değişkenine göre velilerin okul topluluğunca aileleri hoş karşılama boyutunun önem düzeyine ilişkin görüşlerinin $\mathbf{t}$ - testi sonucu

\begin{tabular}{|c|c|c|c|c|c|c|c|c|}
\hline Boyut & Değişken & Kategoriler & $\mathrm{N}$ & $\bar{X}$ & Ss & $\mathrm{Sd}$ & $\mathrm{T}$ & $\mathrm{P}$ \\
\hline \multirow{2}{*}{$\begin{array}{l}\text { Okul } \\
\text { topluluğunca } \\
\text { aileleri hoş } \\
\text { karşılama }\end{array}$} & \multirow{2}{*}{$\begin{array}{l}\text { Çocuk } \\
\text { Sayıs1 }\end{array}$} & $1-2$ & 111 & 39.62 & 4.17 & \multirow[t]{2}{*}{171} & \multirow[t]{2}{*}{3.79} & \multirow[t]{2}{*}{.000} \\
\hline & & 3 ve üzeri & 62 & 36.73 & 5.76 & & & \\
\hline
\end{tabular}

Tablo 4'teki analiz sonucuna göre, 1 veya 2 çocuk sahibi olan velilerin okul topluluğunca aileleri hoş karşılama boyutuna ilişkin görüşleri 3 ve üzeri çocuk sahibi olan velilerin görüşlerine göre daha olumludur $\left[\mathrm{t}_{(171)}=3.79 ; \mathrm{p}<0,05\right]$.

Tablo 5'teki analiz sonuçlarına göre velilerin görüşleri yaş $\left[\mathrm{F}_{(2-165)}=3.09 ; \mathrm{p}<.05\right]$, okula giden çocuk sayısı $\left[\mathrm{F}_{(2-170)}=3.10 ; \mathrm{p}<.05\right]$ değişkenlerine göre anlamlı fark göstermektedir. Farkın kaynağını bulmaya yönelik yapılan Scheffe testi sonucuna göre yaşı 44 ve üzeri olan velilerin, yaşı 25-33 ve 34 - 43 arasında olan velilere göre; okula giden çocuk sayısı 3 ve üzeri olan veliler sınıftaki okula giden çocuk sayısı 1 ve 2 olan velilere göre daha olumsuz düşündükleri ortaya çıkmaktadır. Yaşı 44 ve üzeri olan velilerin öğrenci başarısını desteklemek boyutunun önem düzeyine ilişkin görüşleri yaşı 25-33 arası ve 34-44 arası olan velilerin görüşlerine göre daha olumsuzdur $\left[\mathrm{F}_{(2 ; 165)}=3.46 ; \mathrm{p}<0,05\right]$. 
Tablo 5: Yaş, okula giden çocuk sayısı değişkenlerine göre velilerin okul topluluğunca aileleri hoş karşılama ve öğrenci başarısını desteklemek boyutunun önem düzeyine ilişkin görüsslerinin ANOVA sonuçları

\begin{tabular}{|c|c|c|c|c|c|c|c|c|c|}
\hline Boyut & Değişken & Kategoriler & $\mathrm{N}$ & $\bar{X}$ & Ss & $\mathrm{Sd}$ & $\mathrm{F}$ & $\mathrm{p}$ & $\begin{array}{c}\text { Anlamlı } \\
\text { Fark } \\
\text { (Scheffe ) }\end{array}$ \\
\hline \multirow{6}{*}{$\begin{array}{l}\text { Okul } \\
\text { topluluğunca } \\
\text { aileleri hoş } \\
\text { karşılama }\end{array}$} & \multirow{3}{*}{ Yaş } & 1. 25-33 aras1 & 48 & 38.46 & 5.38 & \multirow[t]{3}{*}{$2 ; 165$} & \multirow[t]{3}{*}{3.09} & \multirow[t]{3}{*}{.048} & \multirow{3}{*}{$\begin{array}{l}3-1 \\
3-2\end{array}$} \\
\hline & & 2. 34-43 aras1 & 89 & 39.30 & 4.42 & & & & \\
\hline & & 3. 44 ve üzeri & 31 & 36.78 & 5.28 & & & & \\
\hline & \multirow{3}{*}{$\begin{array}{l}\text { Okula } \\
\text { Giden } \\
\text { Çocuk }\end{array}$} & 1.1 çocuk & 62 & 39.41 & 5.11 & \multirow[t]{3}{*}{$2 ; 170$} & \multirow[t]{3}{*}{3.10} & \multirow[t]{3}{*}{.047} & \multirow[t]{3}{*}{$1-3$} \\
\hline & & 2.2 çocuk & 76 & 38.72 & 4.13 & & & & \\
\hline & & $\begin{array}{l}3.3 \text { çocuk ve } \\
\text { üzeri }\end{array}$ & 35 & 36.83 & 6.06 & & & & \\
\hline \multirow{3}{*}{$\begin{array}{l}\text { Öğrenci } \\
\text { Başarısını } \\
\text { desteklemek }\end{array}$} & \multirow{3}{*}{ Yaş } & 1. 25-33 aras1 & 48 & 51.24 & 4.66 & \multirow[t]{3}{*}{$2 ; 165$} & \multirow[t]{3}{*}{3.46} & \multirow[t]{3}{*}{.034} & \multirow{3}{*}{$\begin{array}{l}3-1 \\
3-2\end{array}$} \\
\hline & & 2. 34-43 aras1 & 89 & 50.91 & 4.58 & & & & \\
\hline & & 3. 44 ve üzeri & 31 & 48.50 & 6.00 & & & & \\
\hline
\end{tabular}

Velilerin uygulama düzeyine ilişkin görüşleri incelendiğinde, görüşlerinin etkili iletişim boyutunda cinsiyet değişkenine, öğrenci başarısını desteklemek boyutunda cinsiyet, yaş ve eğitim durumu değişkenlerine ve toplumla işbirliği boyutunda cinsiyet değişkenine göre farklılaştı̆̆ ortaya çıkmıştır. $\mathrm{Bu}$ değişkenlere göre yapılan t-testi ve ANOVA analizi sonuçları Tablo 6'da verilmiştir.

Tablo 6: Cinsiyet değişkenine göre etkili iletişim sağlama, öğrenci başarısını desteklemek ve toplumla işbirliği boyutlarının uygulama düzeyine ilişkin görüş̧lerinin t-testi sonucu

\begin{tabular}{|c|c|c|c|c|c|c|c|c|}
\hline Boyut & Değişken & Kategoriler & $\mathrm{N}$ & $\bar{X}$ & Ss & $\mathrm{Sd}$ & $\mathrm{T}$ & $\mathrm{P}$ \\
\hline Etkili İletişim Sağlama & Cinsiyet & $\begin{array}{l}\text { Kadın } \\
\text { Erkek }\end{array}$ & $\begin{array}{c}119 \\
54\end{array}$ & $\begin{array}{l}21.76 \\
19.78\end{array}$ & $\begin{array}{l}4.17 \\
4.84\end{array}$ & 171 & 2.75 & .006 \\
\hline $\begin{array}{l}\text { Öğrenci Başarısını } \\
\text { Desteklemek }\end{array}$ & Cinsiyet & $\begin{array}{l}\text { Kadın } \\
\text { Erkek }\end{array}$ & $\begin{array}{c}119 \\
54\end{array}$ & $\begin{array}{l}39.96 \\
35.77\end{array}$ & $\begin{array}{l}10.20 \\
10.66\end{array}$ & 171 & 2.46 & .015 \\
\hline Toplumla İşbirliği & Cinsiyet & $\begin{array}{l}\text { Kadın } \\
\text { Erkek }\end{array}$ & $\begin{array}{c}119 \\
54\end{array}$ & $\begin{array}{l}17.18 \\
15.58\end{array}$ & $\begin{array}{l}4.60 \\
5.06\end{array}$ & 171 & 2.05 & .04 \\
\hline
\end{tabular}

Tablo 6'teki analiz sonucuna göre, kadın velilerin etkili iletişim sağlama boyutuna ilişkin $\left[\mathrm{t}_{(171)}=2.75 ; \mathrm{p}<0,05\right]$, etkili öğrenci başarısını desteklemek boyutuna $\left[\mathrm{t}_{(171)}=2.46 ; \mathrm{p}<0,05\right]$, toplumla işbirliği boyutuna $\left[\mathrm{t}_{(171)}=2.05 ; \mathrm{p}<0,05\right]$.ilişkin görüşleri erkek velilerin görüşlerine göre daha olumludur. 
Tablo 7: Yaş ve eğitim durumu değişkenlerine göre velilerin öğrenci başarısını desteklemek boyutunun uygulama düzeyine ilişkin görüşlerinin anova analizi sonuçları

\begin{tabular}{|c|c|c|c|c|c|c|c|c|c|}
\hline Boyut & Değişken & Kategoriler & $\mathrm{N}$ & $\bar{X}$ & Ss & $\mathrm{Sd}$ & $\mathrm{F}$ & $\mathrm{p}$ & $\begin{array}{c}\text { Anlamlı } \\
\text { Fark } \\
\text { (Scheffe ) }\end{array}$ \\
\hline \multirow{6}{*}{$\begin{array}{l}\text { Öğrenci } \\
\text { Başarısını } \\
\text { Desteklemek }\end{array}$} & \multirow[t]{3}{*}{ Yaş } & 1. 25-33 aras1 & 48 & 42.17 & 9.70 & \multirow[t]{3}{*}{$2 ; 165$} & \multirow[t]{3}{*}{3.77} & \multirow[t]{3}{*}{.025} & \multirow{3}{*}{$\begin{array}{l}1-2 \\
1-3\end{array}$} \\
\hline & & 2. $34-43$ aras1 & 89 & 37.86 & 10.52 & & & & \\
\hline & & 3. 44 ve üzeri & 31 & 36.45 & 10.43 & & & & \\
\hline & \multirow{3}{*}{$\begin{array}{l}\text { Eğitim } \\
\text { Durumu }\end{array}$} & 1.İlkokul & 60 & 41.31 & 9.08 & \multirow[t]{3}{*}{$2 ; 160$} & \multirow[t]{3}{*}{3.74} & \multirow[t]{3}{*}{.026} & \multirow[t]{3}{*}{$1-3$} \\
\hline & & 2.Lise & 62 & 37.45 & 10.56 & & & & \\
\hline & & 3.Üniversite & 41 & 36.07 & 11.30 & & & & \\
\hline
\end{tabular}

Tablo 7'deki analiz sonuçlarına göre velilerin görüşleri yaş $\left[\mathrm{F}_{(2-165)}=3.77 ; \mathrm{p}<.05\right]$ ve eğitim durumu $\left[\mathrm{F}_{(2-160)}=3.74 ; \mathrm{p}<.05\right]$ değişkenlerine göre anlamlı fark göstermektedir. Farkın kaynağını bulmaya yönelik yapılan Scheffe testi sonucuna göre yaş1 25-33 olan velilerin yaşı 34-43 arası ve 44 ve üzeri olan velilere göre; ilkokul mezunu velilerin üniversite mezunu velilere göre daha olumlu düşündügü görülmektedir.

Ölçekte velilerin okul aile birliği çalışmalanına ilişkin görüşlerini belirlemek amacıyla iki açik-uçlu soru yöneltilmiştir. Bu sorulara verilen cevapların frekans ve yüzde değerleri Tablo 8'de verilmiştir.

Tablo 8: Okul Aile Birliği’ne ilişkin veli görüşleri

\begin{tabular}{|c|c|c|c|}
\hline $\begin{array}{l}\text { Sorunun } \\
\text { Kapsam1 }\end{array}$ & $\begin{array}{l}\text { Görüşlerden elde edilen temel ifadeler } \\
\text { (Ana içerik, ilgili alıntılardan özetlenerek formüle } \\
\text { edilmiştir.) }\end{array}$ & $\begin{array}{l}\text { Ortaya çikan konular } \\
\text { (Alıntılardan } \quad \text { ortaya } \\
\text { çıan Konular) }\end{array}$ & $\begin{array}{l}\text { Toplam } \\
\text { görüş } \\
\text { sayı1s1 }\end{array}$ \\
\hline \multirow{5}{*}{$\begin{array}{l}\text { Okul aile birliği } \\
\text { seçimleri ile ilgili } \\
\text { görüş ve önerileriniz } \\
\text { nelerdir? }\end{array}$} & -Hiçbir bilgim yok $(19,47,54,65,67,79,82,88,92)$ & Bilgilendirme & 9 \\
\hline & $\begin{array}{l}\text {-Seçimlerin adil ve düzenli olmasını, faydalı kişilerin } \\
\text { seçilmesini isterim }(16,42,55,60,69)\end{array}$ & Seçim & 5 \\
\hline & -Velilere haber verilmeli $(20,44,63,85)$ & Bilgilendirme & 4 \\
\hline & -Kapalı oy kullanılmasını istiyorum $(7,13)$ & Seçim & 2 \\
\hline & -Çok güzel, memnunuz (1) & Memnuniyet & 1 \\
\hline \multirow{2}{*}{$\begin{array}{l}\text { Okul aile birliklerinin } \\
\text { eğitime katkısı ile } \\
\text { ilgili görüş ve } \\
\text { önerileriniz nelerdir? }\end{array}$} & $\begin{array}{l}\text {-Okul aile birliğinin eğitim ve öğretime önemli bir } \\
\text { katk1s1 olduğunu düşünmüyorum }(10,16,27,30,42 \text {, } \\
47,63,67)\end{array}$ & Katkıs1 var & 8 \\
\hline & $\begin{array}{l}\text {-Çocukların eğitim ve öğretimine büyük katkıda } \\
\text { bulunmaktadır. (81) }\end{array}$ & Katk1s1 yok & 1 \\
\hline
\end{tabular}

Tablo 8 incelendiğinde birinci soruya ilişkin toplam 21 görüşün 13'ünün (\%62) bilgilendirme, 6'sının (\% 33,3) seçim, 1'nin ise $(\% 4,8)$ memnuniyet ana kategorisi ile ilgili olduğu görülmektedir. İkinci soruya ilişkin toplam 9 görüşün 8'i $(\% 88,9)$ okul aile birliklerinin eğitime katkısı olmadığı yönündeyken, 1 veli $(\%$ 11,1) okul aile birliklerinin eğitime katkısı olduğu yönünde görüş belirtmiştir. 


\section{TARTIŞMA ve SONUÇ}

Bu çalışmada öncelikle velilerin okul aile işbirliğine ilişkin görüşlerini belirlemek amacıyla "Okul Aile İşbirliği Standartları" ölçeği geliştirilmiştir. Bunun iççin alanyazında belirlenen altı standart temel alınmış ve ölçeğin yapıyı doğrulayıp doğrulamadığını anlamak amacıyla DFA analizi yapılmıştır. Ölçeğin faktör yapısını doğrulamak üzere yapılan DFA sonuçları incelendiğinde uyum indekslerinin istenen düzeyde olduğu görülmektedir. Ölçeğin güvenirliği için yapılan analiz sonucu incelendiğinde Cronbach alfa katsayısının .70 ve üzerinde olduğu görülmektedir. Dolayısıyla 47 madde ve 6 boyuttan oluşan ölçeğin geçerli ve güvenilir bir ölçek olduğunu söylemek mümkündür.

Okul-aile işbirliği standartlarına ilişkin veli görüşlerini ortaya çıkarmak amacıyla yapılan çalışmanın sonuçları incelendiğinde, veliler ölçekteki tüm ifadelere önem düzeyinde çok ya da tamamen katılırken, uygulama düzeyinde orta derecede ya da az katıldıkları görülmektedir. $\mathrm{Bu}$ durum velilerin okul aile işbirliği standartlarına ilişkin ifadeleri önemli bulduklarını ancak yeterince uygulanmadığını düşündüklerini göstermektedir. Velilerin görüşlerine göre veliler kendilerini okula ait hissetmemekte ve okul personeli ailelerin katılımı için yeterince uğraşmamaktadır. Ayrıca okul veli arasında bir iletişim sıkıntısı olduğu görülmektedir. Bu durum alanyazındaki diğer araştırmalarla benzerlik göstermektedir (Doğan , 1995; Aslanargun, 2007). Ayrıca velilere göre okul, okul dışında çocuklar için ne tür öğrenme firsatlarının olduğu konusunda yeterince destek verildiğini düşünmemektedir. Bununla birlikte okul personelinin görevleri hakkında ve ailelerin hak ve sorumlulukları hakkında da bilgilerin de yeterli olmadığını düşünmektedir. Okulun önemli bir işlevi olan toplumla işbirliği konusunda ise veliler okulun yeterli olmadığını düşünmektedir.

Araştırmada cinsiyet değişkenin okul aile işbirliği için önemli bir değişken olduğu ortaya çıkmıştır. Velilerin etkili iletişim, toplumla işbirliği ve öğrenci başarısını desteklemek boyutunun uygulama düzeyine ilişkin görüşleri cinsiyet değişkenine göre farklılık göstermektedir. $\mathrm{Bu}$ boyutlara ilişkin kadın velilerin görüşleri erkek velilere göre daha olumludur. Parsons ve Bales (1955, Akt. Han ve Jun, 2010) ve Jeynes'e (2003) göre de aile katılımı ebeveynin cinsiyetine göre farklılık göstermektedir. Erkekler araçsal bir rol sergilerken kadınlar anlamsal rol sergilemektedir. Araçsal rol çocuğu disiplin altına alma veya para kazanma; anlamsal rol ise çocuğun bakılması, boş zamanların birlikte paylaşılması gibi eylemleri içermektedir. Bu durumda çocuğun eğitimiyle ilgilenmenin kadına düşen bir rol olarak kabul gördüğü söylenebilir. Shumow ve Miller'de (2001) araştırmalarında annelerin okula katılımının babalara göre daha az olduğunu ortaya çıkarmıştır. Shermarn'a göre (2000) kadının iletişim becerileri daha iyi olduğu için iş arkadaşlarını desteklemede, geliştirmede ve işbirliği sağlamada daha başarılıdır. Bu noktada kadınların çocuğun eğitimiyle daha çok ilgilenmesi ve okulla daha çok iletişime geçmesi kadınların erkeklere göre daha olumlu düşünmesine yol aç1yor olabilir.

Yaş değişkenine göre yapılan analizlerde 44 yaş ve üzeri olan velilerin okul topluluğunca aileleri hoş karşılama boyutunun önem ve öğrenci başarısını desteklemek boyutunun önem ve uygulama düzeyine ilişkin görüşlerinin daha olumsuz olduğu görülmektedir. Aile katılımı çocuğun yaşı ilerledikçe azalmaktadır (Grace, Jethro ve Aina, 2012; Fan, 2001; Miedel ve Reynolds, 1999; Çiftçi ve Bal, 2015). Ailelerin erken yaştaki çocukların öğrenmelerine, okul performanslarına ve akademik başarılana katkısı daha fazladır çünkü küçük çocuklar ailelerin okula gelmesine ve okuldaki etkinliklere katılmasına daha olumlu bakmaktadır (Eccles ve Horold, 1993). Bu noktada 44 yaş ve üzeri olan velilerin çocuklarının yaşının genelde daha büyük oluğu düşünülürse araştırma bulgularının diğer araştırma bulgularıyla örtüştügünü söylemek mümkündür. 
Velinin sahip olduğu ve okula giden çocuk sayısı değişkenine göre yapılan analizler sonucunda velilerin okul topluluğunca aileleri hoş karşılama boyutunda önem düzeyine ilişkin görüşlerinin ailenin sahip olduğu çocuk sayısı ve okula giden çocuk sayısı 3 ve üzeri olan velilerin görüşleri diğerlerine göre daha olumsuzdur. Velilerin okulda hoş karşılanması ailenin katılımını artıran önemli bir faktördür. Aile katılımının öğretmenler veya diğer okul personeli tarafından değerli olmadığını hisseden veliler, okul aile işbirliğine daha az istek duymaktadır (HooverDempsey ve Sandler, 1997). Aileleri hoş karşılayan ve katılımlarının değerli olduğunu hissettirilen okullarda veliler okul aile işbirliğine daha etkili katılmaktadır (Eccles ve Horold, 1993). Ancak çocuk sayısının ve okula giden çocuk sayısının fazla olması özellikle sosyo ekonomik düzeyi düşük ailelerde velilerin okulla işbirliği yapmasını engelleyebilir.

Eğitim değişkenine göre yapılan analiz sonucunda velilerin öğrenci başarısını desteklemek boyutunun uygulama düzeyine ilişkin görüşleri eğitim durumu değişkenine göre farklılık göstermekte; ilkokul mezunu olan veliler öğrenci başarısını desteklemeyi daha çok önemsemektedir. Ancak araştırmalarda eğitim düzeyi yükseldikçe ailelerin okula katılımın arttığı ortaya çıkmıştır (Englund, Luckner, Whaley ve Egeland, 2004; Salıc1-Ahioğlu, 2006; Zellman, 1998). Eğitim düzeyi yüksek ailelerin çocuğunun başarısını desteklemeye daha çok önem vermesi beklenirken araştırmada ilkokul mezunu velilerin daha çok önem verdiği ortaya çıkmıștır. Bunun nedeni olarak eğitim düzeyi yüksek velilerin çocuğun okul başarısı için başta kendileri olmak üzere ek kaynaklar sağlaması gösterilebilir. Bu veliler çocuklarının akademik başarısı için gerektiğinde kendileri de destek olabilirler ancak ilkokul mezunu velilerinin bu noktada her şeyi okuldan beklediği söylenebilir. Bu nedenle bu veliler okulun öğrenci başarısını desteklemesini daha çok önemsiyor olabilir.

Velilerin okul aile işbirliği çalışmalarına ilişkin görüşleri incelendiğinde, velilerin öncelikle okul aile birliği seçimlerinden haberi olmadığı ve okul aile birliklerinin eğitime katkısının olmadığını düşündükleri görülmektedir. Okul Aile Birliği’nin kurulmasının amacı okul ile aile arasında bütünleşmeyi gerçekleştirmek, veli ve okul arasında iletişimi ve iş birliğini sağlamak, eğitim-öğretimi geliştirici faaliyetleri desteklemek, maddi olanaklardan yoksun öğrencilerin zorunlu gereksinimlerini karşılamak ve okula maddî katkı sağlamaktır (Okul Aile Birliği Yönetmeliği). Bu noktada veli ve okul arasında bir iletişim eksikliğinden bahsetmek mümkündür. Gökçe'nin (2000) araştırmasında da velilerin, öğretmenin etkili iletişim kurabilmesini, öğretmenlerin kendilerine yardımcı olmalarını ve öğrenci başarısının sağlanmasını istediği görülmektedir. Benzer şekilde bazı araştırma bulguları (Aslan,1984; Koçak, 1988; Doğan, 1995) yöneticilerin okul aile işbirliğinde ilgisiz ve isteksiz olmalarının, yönetici ve öğretmenlerin velileri tanımamalarının ailelerin okula katılımını azalttı̆̆ını ortaya koymaktadır. Ceylan ve Pınar'da (2010) okul aile işbirliğine ilişkin veli ve öğretmen görüşlerini incelediği araştırmasında öğretmenlerin, velilerin okula nasıl katkı sağlayacağını bilmediğini belirttiğini, velilerin ise öğrencilerle ilgili bilgilerin kendilerine ulaştırılmadığını belirttiğini ortaya çıkarmıştır.

Sonuç olarak veliler, okul aile işbirliği ile ilgili standartların önemli olduğunu ancak uygulanmadığını düşünmektedir. Ayrıca veliler okul aile işbirliği adına yapılan etkinliklerden haberdar değildir ve bu işbirliğinin eğitime bir katkı sağlamadığını düşünmektedir. Bu durum velinin katılımını engelleyen bir durum olarak düşünülebilir.

Aileler öğrencinin eğitiminde okulun yanında en etkili kurumu oluşturmaktadır. Öğrenciyi tanımada, yönlendirmede, yeteneğini ve kapasitesini artırmada mutlaka aileyle iş birliğine gidilmelidir. Bunun için veliler okul aile işbirliği konusunda bilgilendirilmeli, faaliyetlerden haberdar edilmelidir, okula geldiğinde hoş karşılanmalı ve okulun bir üyesi olduğu hissettirilmelidir. Velilere okul dışındaki öğrenme firsatları, okul personelinin görevleri, ailelerin hakve sorumlulukları hakkında bilgi verilmelidir. Okulda aileleri kaynaştırmak için etkinlikler 
düzenlenmeli, ailelerin okul etkinliklerine katılımının önündeki engeller araştırılarak bu engeller ortadan kaldırılmalı, ailelerin görüşlerini öğrenmek için araştırmalar yapılmalı, ailelerin yerel yöneticilerle bağlantı kurmasına yardımcı olmalıdır. Ayrıca okullarda okul aile birliklerinin daha etkili işlemesini sağlamak amacıyla, söz konusu standartların okullarda uygulanması sağlanmalıdır.

$\mathrm{Bu}$ araştırmada ilköğretim velilerinin okul aile işbirliği standartlarına ilişkin görüş̧leri incelenmiştir. Bundan sonra yapılacak çalışmalarda okul aile işbirliğinin oluşmasında önemli bir etkiye sahip olan öğretmen ve yöneticilerin görüşlerinin de incelenmesinin ve çalışmanın ortaöğretim kurumları için de yapılmasının yararlı olacağı düşünülmektedir. Ayrıca, "Okul Aile İşbirliği Standartları" ölçeğinde bulunan ölçek maddelerinin okul-aile birliği başkanları için yeterliklere dönüştürülerek, okul-aile birliği başkanlarının bu yeterliklere sahip olma düzeyleri araştırılabilir.

\section{KAYNAKLAR}

Aslan, B. (1984). Ankara merkez ilçelerinde temel eğitimin I. kademe düzeyinde okul-aile ilişkileri. Yayınlanmamış doktora tezi, Hacettepe Üniversitesi, Sosyal Bilimler Enstitüsü, Ankara.

Aslanargun, B. (2007). Okul aile birliği ve öğrenci başarısı üzerine bir araştırma, Manas Üniversitesi Sosyal Bilimler Dergisi, 18, $119-135$.

Bayrakçı, M. ve Dizbay, (2013). Ortaöğretim kurumlarında okul aile birliklerinin okul yönetimine katılım düzeyleri, Sakarya University Journal of Education, 3,1, 98-112

Becher, R. (1984). Parent involvement: A review of research and principles of successful practice. Washington, D.C.: National Institute of Education. [ERIC Abstract].

Bentler, P.M., \& Bonett, D.G. (1980). Significance tests and goodness of fit in the analysis of covariance structures. Psychological Bulletin, 88,3, 588-606.

Berger, E. H. (1987) `Parent involvement: Yesterday and today`, The Elementary School Journal, 3, 96-108

Birk J.ve Blimline, C. (1984).'Parents as career development facilitator: An untapped resource for the counselors`, The School Counselor, 31, 2, 3 10-317.

Brown, T.A. (2015). Confirmatory factor analysis for applied research. NY: The Guilford Press..

Burns, C.P., Roe, B.D. ve Ross, E.P. (1992). Teaching reading in today's elementary schools. Boston Houghton Mifflin Company.

Büyüköztürk, Ş. Kılıç Çakmak, E, Akgün, Ö.E. Karadeniz, Ş. ve Demirel, F. (2010). Bilimsel araştırma yöntemleri , Ankara : Pegem A Akademi.

Ceylan, M. ve Akar, B. (2010). Ortaöğretimde okul- Aile işbirliği ile ilgili öğretmen ve veli görüşlerinin incelenmesi

(Karacasu Lisesi Örneği), Çankırı Karatekin Üniversitesi Sosyal Bilimler Enstitüsü Dergisi, 2, 43-64

Chu E. H. ve Williams, J. D (1996). 'Effects of parental involvement on eight-grade achievement', The School Counselor, 69, 126-142.

Çalışkan, N. ve Ayık, A. (2015). Okul aile birliği ve velilerle iletişim, Ahi Evran Üniversitesi Sosyal Bilimler Dergisi, 1, $2,69-82$.

Çelenk, S. (2003). Okul başarısının ön koşulu: Okul aile dayanışması, İlköğretim Online, 2, 2, 28 -34.

Çiftçi, M. ve Bal, P.N. (2015). Ortaokul öğrencilerinin anne-baba katılım düzeyi ile akademik başarıları arasındaki ilişkinin incelenmesi, International Journal of Human Science, 12,1, 363-384.

Demirbulak, D. (2000). Veli-öğretmen görüşmeleri ile ilgili bir çalışma, Millî Eğitim Dergisi,Nisan-Mayıs-Haziran ,146.

Doğan, E. (1995). Ankara merkez ilçelerindeki ilköğretim okullarında okul-aile iletişiminin engelleri. Yayınlanmamış yüksek lisans tezi. Hacettepe Üniversitesi, Sosyal Bilimler Enstitüsü, Ankara.

Eccles, J.S., ve Horold, R.D. (1993). Parent-School involvement during the early adolescent years. Teachers College Record, 94,3, 568-587.

Epstein, J.L. (2001). School, family and community partnership, Boulder, CO: Westview Pres. 
Englund, M. M., Luckner, A. E., Whaley, G. J. L., \& Egeland, B. (2004). Children's achievement in early elementary school: longitudinal effects of parental involvement, expectations, and quality of assistance. Journal of Educational Psychology, 96, 4 , 723-730.

Fan, X. (2001). Parental involvement and students' academic achievement: a growth modeling analysis. Journal of Experimental Education, 70 , 1, 27-53.

Gökçe, E. (2000). İlköğretimde okul aile işbirliğinin geliştirilmesi, Pamukkale Üniversitesi Eğitim Fakültesi Dergisi [Çevrim-içi: http://pauegitimdergi.pau.edu.tr], Erişim tarihi: 07.06.2012.

Grace, A.M., Jethro, O.O. ve Aina, F.F. (2012). Roles of parent on the academic performance of pupils in elementary schools, International Journal of Academic Research in Business and Social Sciences, 2,1, 196-201.

Griffith, J. (1996). 'Relation of parental involvement, empowerment, and school traits to student academic performance', The Journal of Educational Research, 90, 1, 33-41.

Han, Y.S. ve Jun, W.P. (2010), Parental involvement and its effects on satisfaction of parent -child relationship, Sunway Academic Journal, 7, 48-62.

Henderson, A.T., ve Berla, N. (1994). A new generation of evidence: The family is critical to student achievement. Washington, D.C.: National Committee for Citizens in Education.

Hooper, D., Coughlan, J., \& Mullen, M.R. (2008). Structural equation modelling: Guidelines for determining model fit. The Electronic Journal of Business Research Methods, 61, 53-60.

Hoover-Dempsey,K.V. ve Sandler, H.M. (1997). Why do parents become involved in their children's education? Review of Educational Research, 67,1, 3-42.

Hoover-Dempsey, K.V., Whitaker, M.C. ve Ice C.L. (2010). Motivation and commitment to family school partnership, Handbook of school familiy partmership (Ed. Christenson S.L. ve Reschly, A.L) UK: Routledge, 30-60.

Hoyle, R.H., \& Smith, G.T. (1994). Formulating clinical research hypotheses as structural equation models: A conceptual overview. Journal of Consulting and Clinical Psychology, 62,3, 429-440.

Hu, L., \& Bentler, P.M. (1998). Fit indices in covariance structure modeling: Sensitivity to underparameterized model misspecification. Psychological Methods, 3,4, 424-453.

Jacobs, G. (1982. Children`s Needs: Implications for Guidance Programs In the 1980`s`, The School Counselor, 30, 5055.

Jeynes, W.H. (2003). A Meta-Analysis: The effects of parental involvement on minority children's academic achievement, Education and Urban Society, 35, 2002-218.

Jeynes, W.H. (2005). A meta-analysis of the relation of parental involvement to urban elementary school student academic achievement, Urban Education, 40, 237-269.

Kline, R.B. (2011). Principles and practice of structural equation modeling. NY: The Guilford Press.

Koçak, Y. (1988). Okul aile iletişiminin engelleri. Yayınlanmamış yüksek lisans tezi. Hacettepe Üniversitesi, Sosyal Bilimler Enstitüsü, Ankara.

MacCallum, R.C., Widaman, K.F., Preacher, K.J., \& Hong, S. (2001). Sample size in factor analysis: The role of model error. Multivariate Behavioral Research, 36,4, 611-637.

Marchant, G. J., Paulson, S. E. \& Rothlisberg, B. A. (2001). Relations of middle school students' perceptions of family and school contexts with academic achievement. Psychology in the Schools, 38, 6, 505-519

Miedel, W. T., ve Reynolds, A. J. (1999). Parent involvement in early intervention for disadvantaged children. Journal of School Psychology, 37, 4, 379-401.

Milli Eğitim Bakanlığı Okul Aile Birliği Yönetmeliği (2012). Resmi Gazete:9 Şubat 2012. Sayı: 28199

Milli Eğitim Temel Kanunu (1973). Resmi Gazete: 24.6.1973, Say1: 14574

Morgan, V., Dunn, S., Cairns, E. ve Fraser G. (1993). How do parents choose a school for their child? An example of the exercise of parental choice. Educational Research, 5(2),139-148.

National Standards for Implementation Guide (2009). (www.pta.org adresinden 01. 03. 2012 tarihinde indirilmiştir).

Pomerantz, E.M. ve Moorman, E.A. (2007). The how, whom and why of parents' 1nvolvement in childrens' academic lives: More is not always better, Review of Educational Research, 77, 373 - 410. 
Roberts, H. C. (1984). `Uncloseting the cumulative record: A parent-student-counselor conferences projects`, The School Counselor, Vol.31, 1984, s.54-61.

Salıc1-Ahioğlu, Ş. (2006). Öğretmen ve veli görüşlerine göre farklı sosyoekonomik düzeydeki ailelerin ilköğretim birinci sınıf öğrencilerinin okuma yazma sürecini etkileme biçiminin değerlendirilmesi. Yayınlanmamış yüksek lisans tezi. Çukurova Üniversitesi, Sosyal Blimler Enstitüsü, Adana.

Sammons, P. (1996). Complexities in the judgement of school effectiveness, Educational Research and Evaluation, 2,2, $113-49$.

Schermelleh-Engel, K., Moosbrugger, H., \& Muller, H. (2003). Evaluating the fit of structural equation models: Tests of significance and descriptive goodness-of-fit measures. Methods of Psychological Research Online, 8(2), 23-74.

Sherman, A. (2000). Women managing/managing women: female leadership in rural school settings Education, Educational Management and Administration, 28, 133-143.

Shumow, L. ve Miller, J. D. (2001). Parents' at home and at-school academic involvement with young adolescents. Journal of Early Adolescence, $21,1,68-92$.

Sümer, N. (2000). Yapısal eşitlik modelleri: Temel kavramlar ve örnek uygulamalar. Türk Psikoloji Yazıları, 3,6, 49-74.

Şimşek, Ö.F. (2007). Yapısal eşitlik modellemesine giriş: Temel ilkeler ve lisrel uygulamaları. Ankara: Ekinoks Yayınevi.

Tutkun, Ö. ve Köksal, A. (2000). Okul- aile işbirliğinde yeni yaklaşımlar, Eğitim Araştırmaları Dergisi, 8, 216-224.

Zellman, G. L. (1998). Understanding the impact of parental school involvement on children's educational outcomes. Journal of Eduational Research, 91(6), 370-381.

\section{Extended Abstract}

It is difficult for schools to offer an effective educational service on their own. That's why initially classroom teachers, school managers need support from parents during this process. Despite of the establishment of some associations like parent-teachers' associations, school protection associations for years, it is the fact that these associations could not fulfill their functions at an expected level. In the related literature, the importance of school-parents cooperation has been emphasized but the standards concerning to what extend this cooperation have not been taken into consideration. The purpose of this research is to reveal the views of the elementary school parents concerning family-school cooperation standards which are welcoming all families into the school community, communicating effectively, supporting student success, speaking up for every child, sharing power, collaborating with community (National Standarts for Implementation Guide, 2009).

In the research, it has been put forward that gender is an important variable in school-parent cooperation. With regard to application-level of parents' views concerning effective communication, cooperation with the society and support for students' success differ due to the gender variable. In these dimensions, views from mothers are more positive than the fathers. From the analyses based on the age variable, it has been observed that the parents who are 44 and above think more negatively on the importance-level of "welcoming all families into the school community "and the importance and applicationlevel of the supporting students success. According to the result of the analysis made based on the number of the children that the parents have and the number of the children attending schools variables, it has been observed that parents who have 3 or more children and ones who have 3 or more children attending school have more negative views than the others concerning the importance level of the welcoming all families into the school community. Results of the analyses revealed that, parents' views concerning the application level of supporting students' success aspect differ in accordance with the educational background. Elementary school graduate parents give more importance to supporting students' success. When the qualitative analysis results are examined, it has been observed that primarily parents are uninformed of the selection of parentteachers' association and they think that parent-teachers' associations do not have any contribution to education.

In the literature it has been observed that parent involvement differs according to parents' gender. Whereas males perform an instrumental role, females perform semantic roles. Instrumental role aims to take the child under control or making money while semantic role aims activities like taking care of the child or sharing some leisure time with the child (Parsons and Bales, 1955, as cited in Han and Jun, 2010). From this stand, it can be claimed that taking care of a child is a role which must be fulfilled by the men. Family 
involvement decreases as the child grows up (Grace, Jethro and Aina, 2012). The level of family contribution for the children's learning, school performance and academic success is higher at early ages because children react positively to their parents when they visit the school and take part in the school activities (Eccles and Horold, 1993). At this point, when the fact that the parents who are 44 or above have older children is taken into consideration, it is possible to claim that research findings are in accordance with the other research findings. Welcoming all families into the school community is an important factor that increases family involvement in school. When the parents feel that, if their involvement is not considered as important by the school staff, then they are not willing to participate into school activities (Hoover-Dempsey and Sandler, 1997). However, if the number of children or the number of the children attending school is more, this can be an obstacle for family school cooperation especially for the families especially who have a low socioeconomical background. Although it has been expected that parents who have a good educational background give more importance to supporting the child's success, in the researches it has been found out that elementary school graduate parents give more importance to this issue. This can be explained by the fact that parents' who have a good educational background can provide their children with extra sources, particularly themselves.

In conclusion, parents think that the standards concerning family school cooperation are important however they have not been put into practice. Families are the most effective communities besides schools for students' education. There must be cooperation with families for identifying, guiding students and increasing their skills and capabilities. To do this, parents must be informed about school-family cooperation, and the activities, when they come to school, they should be welcomed to school and they should feel as a member of the school. Parents should be informed about learning opportunities which are outside the school and the duties of school staff. In school, also school activities must be organized for families. The barriers that prevent family participation must be searched. Moreover, in order to ensure more efficient processing of school-parent cooperation, these standards should be implemented in different level of education.

In this research, the views of elementary school parents about school-family cooperation standards have been analyzed. It has been considered that it will be beneficial to observe and study about the views of the teachers and school managers who have highly important roles for school-family cooperation at secondary schools in the studies which will be carried out in future. In addition, the items included in the research scale can be redesigned and developed as competencies for the president of School Parent Association. 